\title{
Heavy Metal Content (Hg. Pb. Cd and Fe) of CHU-MEL Effluents Discharged in the Cotonou Lagoon (Benin)
}

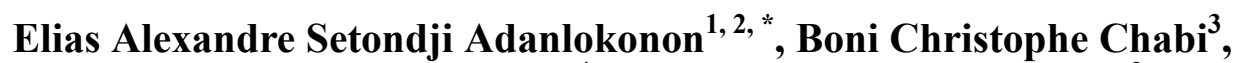 \\ Wilfried Gbedode Kanhounnon ${ }^{4}$, Dogbe Clement Adjahouinou ${ }^{2}$, Etiennette Dassi ${ }^{5}$, \\ Marc Sohounou ${ }^{1}$, Adjouavi Yvette Deguenon ${ }^{1}$, Patrick Aleodjrodo Edorh ${ }^{1}$ \\ ${ }^{1}$ Department of Biochemistry and Cellular Biology, University of Abomey-Calavi, Abomey-Calavi, Benin \\ ${ }^{2}$ Department of Zoology, University of Abomey-Calavi, Abomey-Calavi, Benin \\ ${ }^{3}$ Department Fundamental and Biological Sciences, University of Parakou, Parakou, Benin \\ ${ }^{4}$ Department of Chemistry, Faculty of Science and Technology, University of Abomey-Calavi, Abomey-Calavi, Benin \\ ${ }^{5}$ Ministry of the Environment and Sustainable Development, Cotonou, Benin
}

\section{Email address:}

aeaset22@gmail.com (E. A. S. Adanlokonon), elialexandresetondji@yahoo.fr (E. A. S. Adanlokonon), chabichrst@yahoo.fr (B. C. Chabi), wilkan007@yahoo.fr (W. G. Kanhounnon), clementiofr@yahoo.fr (D. C. Adjahouinou), etienetted@yahoo.fr (E. Dassi), borismarcs@gmail.com (M. Sohounou), deguenonyvette01@gmail.com (A. Y. Deguenon), patrickedorh@yahoo.fr (P. A. Edorh)

${ }^{*}$ Corresponding author

\section{To cite this article:}

Elias Alexandre Setondji Adanlokonon, Boni Christophe Chabi, Wilfried Gbedode Kanhounnon, Dogbe Clement Adjahouinou, Etiennette Dassi, Marc Sohounou, Adjouavi Yvette Deguenon, Patrick Aleodjrodo Edorh. Heavy Metal Content ( $\mathrm{Hg}$. Pb. Cd and Fe) of Chu-mel Effluents Discharged in the Cotonou Lagoon (Benin). International Journal of Environmental Protection and Policy.

Vol. 7, No. 4, 2019, pp. 109-116. doi: 10.11648/j.ijepp.20190704.12

Received: July 11, 2019; Accepted: August 12, 2019; Published: August 26, 2019

\begin{abstract}
This study is conducted to characterize the heavy metal contamination of CHU-MEL effluents discharged into the Cotonou lagoon in order to assess the potential risk of these discharges for this ecosystem. To achieve this objective, the effluents collected at the end of the pipes acting as weirs in the lagoon were analyzed. The results from physico-chemical and heavy metals analyzes have made it possible to assess the quality of the effluents. The values of $\mathrm{pH}$, temperature, conductivity, TDS and dissolved oxygen measured in situ are, on average, $7.95 ; 29.60^{\circ} \mathrm{C} ; 639.60 \mu \mathrm{S} / \mathrm{cm} ; 457.48 \mathrm{mg} / 1 \mathrm{and} 0.22 \mathrm{mg} / \mathrm{L}$. The determination of heavy metals in the effluents showed low levels of contamination. The average levels of lead, cadmium, mercury and total iron are $0.1727 \mathrm{mg} / \mathrm{L}, 0.0261 \mathrm{mg} / \mathrm{L}, 0.0010 \mathrm{mg} / \mathrm{L}$ and $0.25 \mathrm{mg} / \mathrm{L}$, respectively. This study shows that most of the parameters studied in the CHU-MEL effluent are in compliance with the standards. These effluents therefore pose a low risk for the aquatic organisms of the receiving environment, this added to the dilution effect of the effluents in the waters of the lagoon. However, the continual discharge of these effluents into the lagoon with their share of heavy metals.
\end{abstract}

Keywords: Aquatic Environment, Heavy Metal, Hospital Effluents, Pollution

\section{Introduction}

Pollution of aquatic environments in developing countries has been an international concern for decades. In fact, water pollution in these countries has already taken considerable proportions for more than a half century [1]. In addition, environmental protection requires knowledge of the destiny of these pollutants in the environment and their effects on aquatic ecosystems [2]. Among the sources of pollution of the aquatic environment, the discharge of hospital effluents is particularly important. The discharge generated by hospital activities may be dangerous for humans and their environment given the nature and importance of the specific substances they contain (drug residues, chemical reagents, antiseptics, detergents, X-rays developers and fixer...). Their evacuation, as well as the traditional urban discharges, to the municipal sanitation network without prior treatment [3] also contribute to such situation. Among other pollutants, hospital effluents contain and trap heavy metals in aquatic 
environments [4-6]. These heavy metals are source of serious ecological problems. This is linked, on the one hand, to their ability to be found in food chains inner the biosphere and on other hand, to their toxicity. Also, their ability to bioaccumulate and bio-amplify in several aquatic species has devastating effects on the aquatic environment [7-8].

In Benin, according to Decree $\mathrm{N}^{\circ} 2006-087$ of 8 March 2006 approving the national hospital hygiene policy document, "Most health centers lack appropriate structures for the collection and treatment of liquid waste (activated sludge treatment or bacterial bed stations). In some cases, liquid wastes are dumped in washbasins and drained to septic tanks. In other cases, they are evacuated directly into the public sewers when they exist, or released into the nature" [9]. When treatment systems exist, studies revealed the inefficiency of the treatments done on the effluents. This is the case, for example, of CNHU-HKM, the largest national hospital. The comparative effluents analysis at the inlet and the outlet of CNHU-HKM treatment station, has shown that chemical and biological treatments are inefficient [10]. Concerning the CHU-MEL, a characterization study of its effluents discharged into the Cotonou lagoon also revealed the inefficiency of treatment processes [11]. The discharge of these effluents into aquatic environments contributes to the pollution of these ecosystems and exposes people to infections caused by multi-resistant microorganisms.

This work aimed to assess the heavy metals content of the CHU-MEL effluents with the goal to evaluate the potential risk of their rejection in Cotonou lagoon.

\section{Material and Methods}

\subsection{Field of Study}

The present study is conducted on effluents from the
University Hospital Center of Mother and Child Lagoon (CHU-MEL). This hospital is located in the city of Cotonou at the edge of the Cotonou Lagoon in the commercial area, not far from the Coulibaly Technical High School (Figure 1).

Created in 1958 in the medical district, the CHU-MEL had later been transferred to the site of the former Commercial Energy Distribution Company (CCDEE) in Tokpahoho. Hence its first name was "Maternité TokpaHoho". After, named Hospital of the Mother and Child of the Lagoon (HOMEL), it became University Hospital Center of Mother and Child of the lagoon (CHU-MEL) in 2015. The CHUMEL is specialized in gynecological, obstetric and pediatric care. It has a capacity of more than 200 beds. The liquid effluents resulting from the various activities of this hospital are drained into the Cotonou lagoon by underground pipes.

Cotonou is the economic capital and the most populated city in Benin. It is located between $6^{\circ} 20^{\prime}$ and $6^{\circ} 23^{\prime}$ of north latitude and between $2^{\circ} 22^{\prime}$ and $2^{\circ} 30^{\prime}$ of east longitude. Limited to the west by commune of Abomey-Calavi and to the east by Sèmè-Kpodji. Cotonou has two natural borders connected by a channel (Cotonou lagoon): Lake Nokoué in the North and the Atlantic ocean in the south [12-13].

Due to its geographical situation, the study area is subjected to a subequatorial climate characterized by two rainy seasons (the heavy one from April to July and the light one from October to November). They mark the flood periods of the continental waters. One the other hand it is also characterized by two dry seasons (one from December to March and the second covering the months of August and September) [13] marking periods of low water levels in the lagoon.

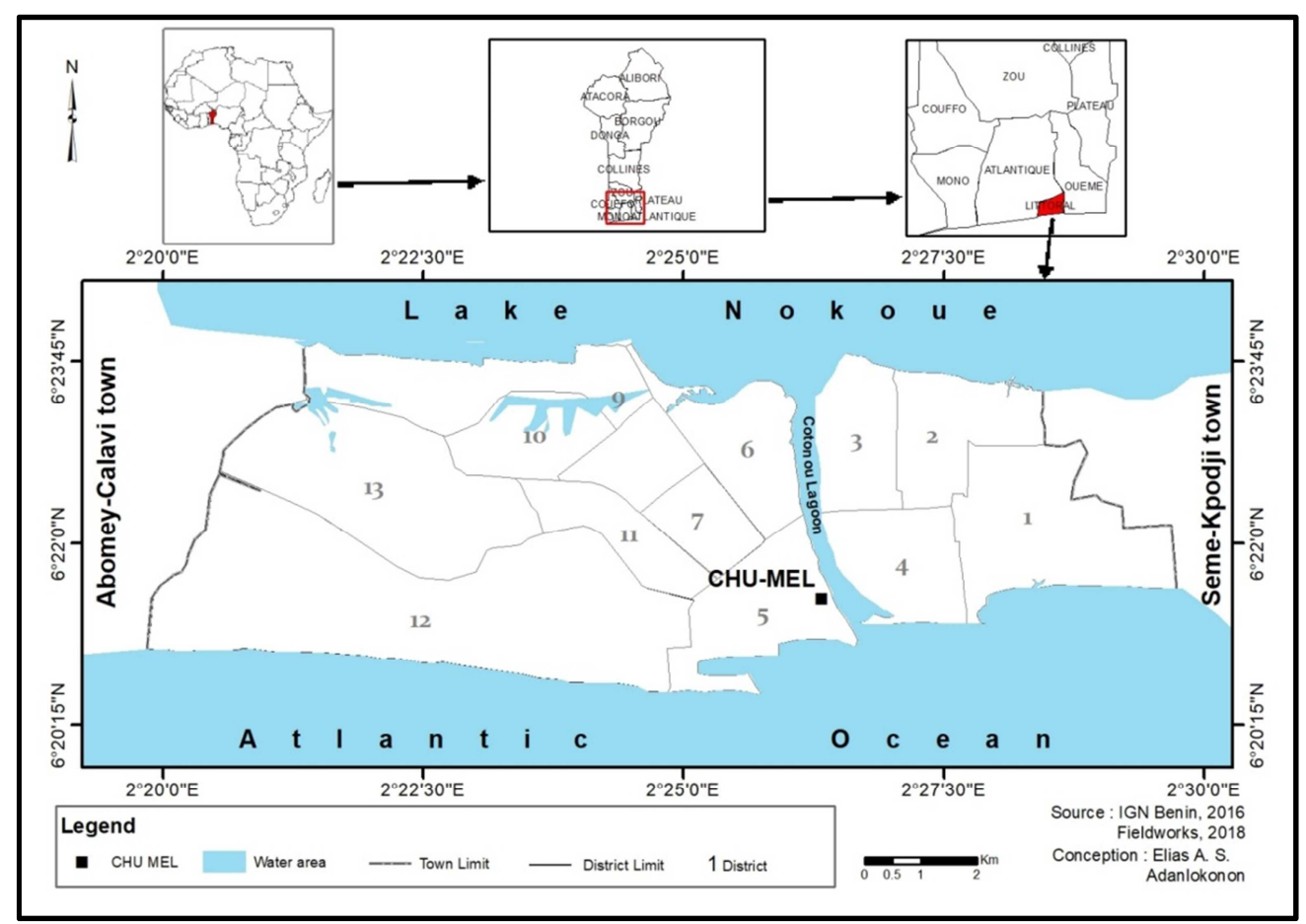

Figure 1. Map of Cotonou town showing the position of the CHU-MEL at the edge of the Cotonou lagoon. 


\subsection{Sampling and Conservation of Effluents}

Four (04) sampling campaigns were conducted in 2018 following the four seasons. Indeed, this work is included in a study on the impact of the CHU-MEL effluents on the zooplankton community of the Cotonou Lagoon, which takes into account the two seasons quoted above. The sampling campaigns took place respectively in January (long dry season (LDS)), in June (long rainy season (LRS)), in August (short dry season (SDS)) and in October (short rainy season (SRS) of the year 2018. During each campaign, five (05) samples (with the interval of 3 hours between two consecutive samplings) were made between $7 \mathrm{am}$ and $7 \mathrm{pm}$ at the end of the ducts discharging the effluents into the lagoon. This time is the accessible moment to the sampling site.

Samples were taken in polystyrene bottles with a volumetric capacity of $500 \mathrm{~mL}$ fully filled, previously washed with distillated water, and after rinsed with effluents (three times). The collected samples were kept in icebox filled of ice to the laboratory for analysis purpose.

At the end of each sampling, all collected samples were gathered in a beaker and then homogenized to obtain a daily composite sample (aliquot). Thus, one (01) daily aliquot of $500 \mathrm{~mL}$ is constituted after each campaign. Diluted nitric acid was added to the samples before its storing at $4^{\circ} \mathrm{C}$ in darkness to ensure stability.

The average amount of effluents discharged into the lagoon has been determined. At each sampling campaign, for three days taken during the sampling week, we measured the flow of effluent discharged into the lagoon. Three measurements were taken during each day (in the morning between 7 and $8 \mathrm{am}$, in the afternoon between 12 and $1 \mathrm{pm}$ and in the evening between 6 and $7 \mathrm{pm}$ ). A yearly flow average is calculated based on that of campaigns. This operation allowed us to evaluate the load of pollutants discharged into the lagoon per day.

\subsection{Analytical Methods}

Temperature, $\mathrm{pH}$, electrical conductivity, total dissolved solid (TDS) and dissolved oxygen content of the effluents were measured in situ with the multi parameter HANNA HI 9829. Cadmium, lead and total iron are measured by molecular absorption spectrophotometry (SAM) using the DR 2800 spectrophotometer. The dithizone method has been used to determine cadmium and lead contents. This measurement is performed after sample mineralization (according to HACH). Total iron is determined by the FerroVer method. The mercury content is determined by cold vapor atomic absorption spectrophotometry (SAA) after incineration under oxygen flux $\left(\mathrm{O}_{2}\right)$ at $254 \mathrm{~nm}$ using DMA80. The liquid samples are weighed and introduced into the DMA-80. Results are displayed directly on a screen connected to the device and are validated according to the method 7473 of the US. EPA [14].

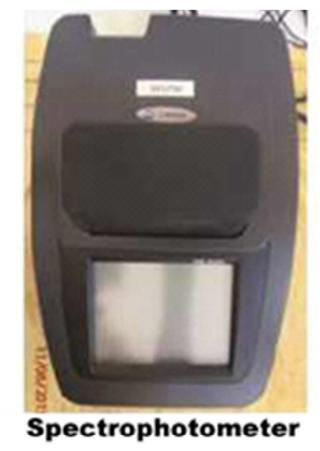

DR 2800

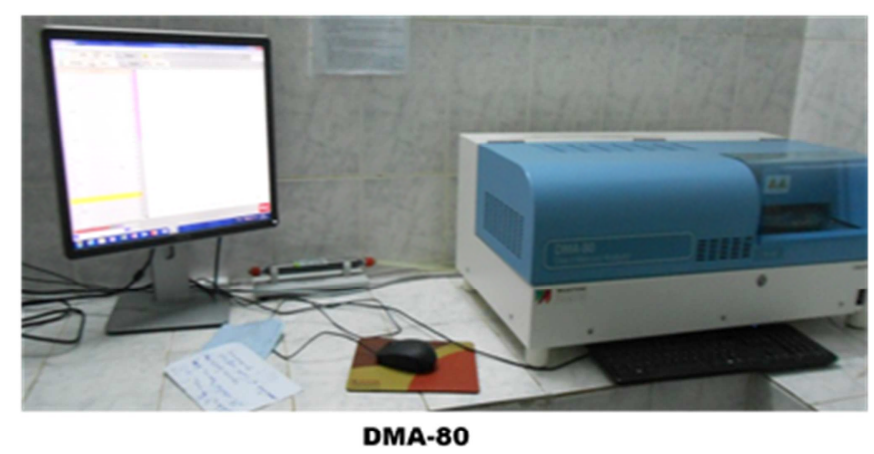

Principle of Operation

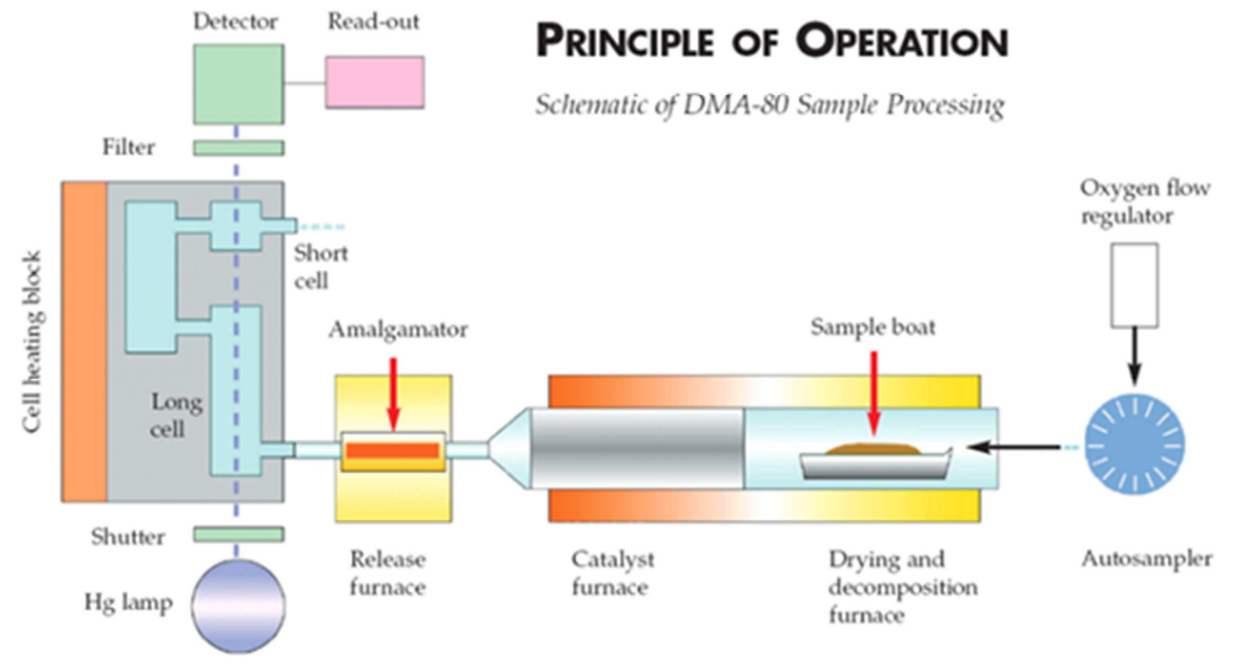

Figure 2. Materials used to dosage of heavy metals. 


\subsection{Statistical Analyzes}

The statistical analyzes and the calculation of means and standard deviation were carried out with STATISTICA software (version 6.1 Statsoft Inc. Tulsa. OK). The Pearson correlation coefficient (r) was calculated to verify the correlation that would exist between physico-chemical and heavy metal parameters [15-16].

\section{Results}

Table 1 presents the average of the various parameters studied and certain effluents discharge standards in the natural environment.

Most of the parameters (physicochemical and heavy metals) studied except the dissolved oxygen content, are in accordance with wastewater discharge standards [17-20].

Table 1. Averages and standard deviations of physicochemical parameters and measured heavy metals contents compared to some Standards.

\begin{tabular}{|c|c|c|c|c|c|c|c|c|}
\hline \multirow{2}{*}{ Parameters } & \multirow{2}{*}{ Unit } & \multirow{2}{*}{ Mini } & \multirow{2}{*}{ Maxi } & \multirow{2}{*}{ Mean \& SD } & \multicolumn{4}{|l|}{ Standards } \\
\hline & & & & & Benin [17] & Egypt [18] & France [19] & Morocco [20] \\
\hline Temperature & ${ }^{\circ} \mathrm{C}$ & 28.52 & 30.3 & $29.60 \pm 0.7978$ & - & 30 & - & 30 \\
\hline $\mathrm{pH}$ & & 5.56 & 10.76 & $7.95 \pm 2.1373$ & $6-9$ & - & - & $5.5-9.5$ \\
\hline Dissolved oxygen & $\mathrm{mg} / \mathrm{l}$ & 0.16 & 0.25 & $0.22 \pm 0.0395$ & $\geq 5$ & - & - & - \\
\hline $\begin{array}{l}\text { Electrical } \\
\text { conductivity }\end{array}$ & $\mu \mathrm{S} / \mathrm{cm}$ & 388.02 & 1273 & $639.60 \pm 425.81$ & 2000 & - & - & - \\
\hline TDS & $\mathrm{mg} / \mathrm{l}$ & 72.31 & 1272 & $457.48 \pm 548.99$ & - & - & - & - \\
\hline Cadmium & $\mathrm{mg} / 1$ & 0.0156 & 0.0319 & $0.0261 \pm 0.0072$ & 1 & 0.05 & 0.001 & 0.25 \\
\hline Mercury & $\mathrm{mg} / \mathrm{l}$ & 0.0007 & 0.0012 & $0.0010 \pm 0.0003$ & 0.03 & 0.005 & 0.00003 & 0.05 \\
\hline Total iron & $\mathrm{mg} / \mathrm{l}$ & 0.0500 & 0.3700 & $0.2500 \pm 0.1407$ & - & 1.5 & - & 5 \\
\hline
\end{tabular}

SD: Standard Deviation

Table 2. Comparison test of the average of the lead, cadmium and mercury to beneneses standard $(N=4)$.

\begin{tabular}{llll}
\hline & Mean \& SD & Beneneses standard & P \\
\hline Lead & $0.1727 \pm 0.1018$ & 1 & 0.000507 \\
Cadmium & $0.0261 \pm 0.0072$ & 1 & 0.000000 \\
Mercury & $0.0010 \pm 0.0003$ & 0.03 & 0.005151 \\
\hline
\end{tabular}

\subsection{Physicochemical Parameters}

Figures (3, 4 and 5) show the respective variation in temperature, $\mathrm{pH}$, conductivity, TDS and dissolved oxygen. Their respective averages are: $29.60 \pm 0.80{ }^{\circ} \mathrm{C} ; 7.95 \pm 2.14$; $639.60 \pm 425.81 \mu \mathrm{S} / \mathrm{cm} ; 457.48 \pm 548.99 \mathrm{mg} / \mathrm{L}$ and $0.22 \pm$ $0.04 \mathrm{mg} / \mathrm{L}$.

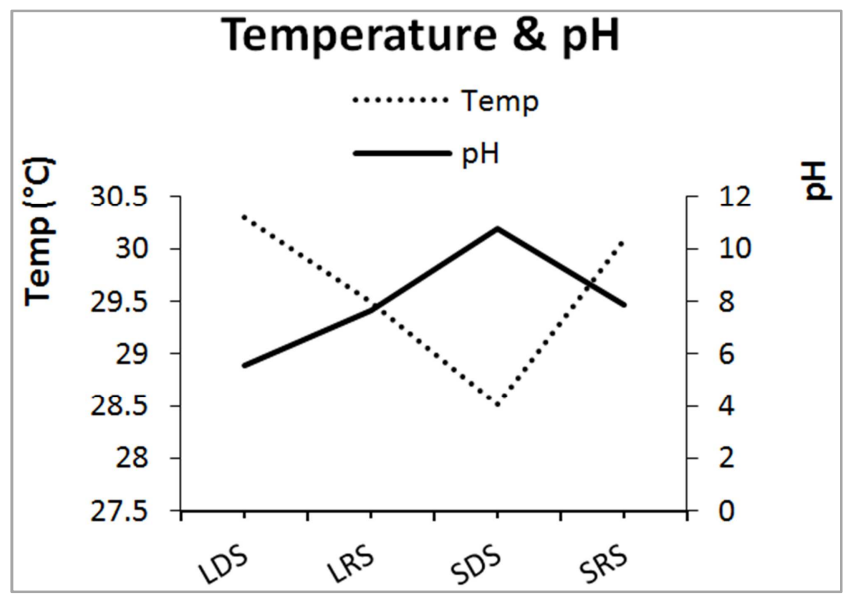

Figure 3. Temperature and $p H$ variation.

\section{Conductivity \& TDS}

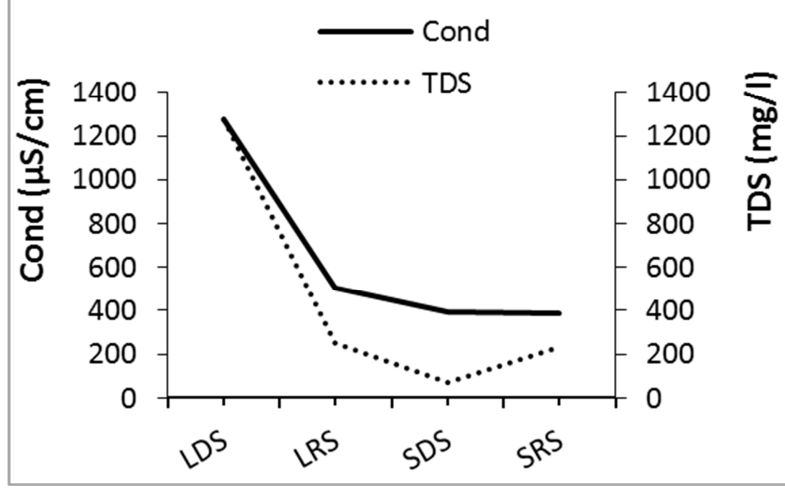

Figure 4. Conductivity and TDS variation.

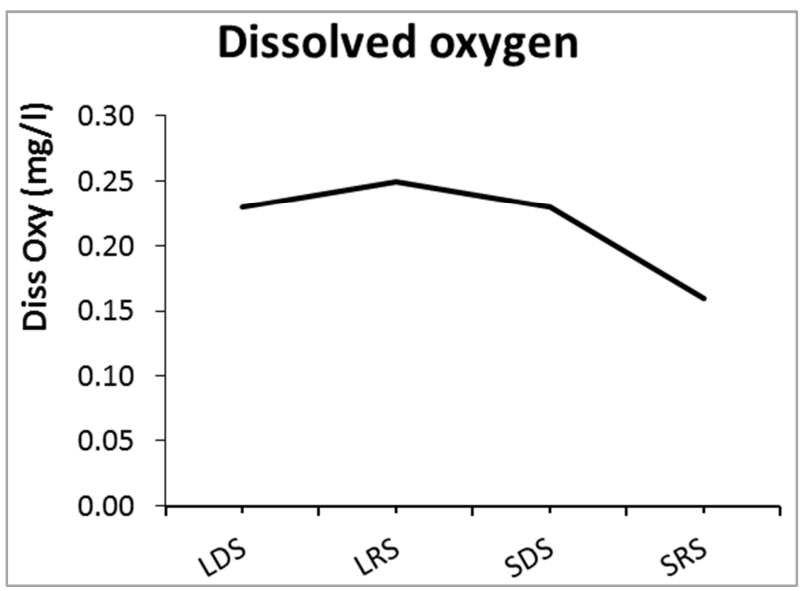

Figure 5. Dissolved oxygen variation. 


\subsection{The Metal Content}

\subsubsection{Metal Loading in Effluents}

To determine the load of metals in the effluents, we first assessed the average amount of effluent discharged per day into the lagoon. We therefore proceeded to the measure of the average flow.

The average flow D measured during our work is $1.32 \mathrm{~L} / \mathrm{s}$, what equals to in a daily average effluents quantity of:

$$
Q=D * 3600 * 24
$$

$$
Q=114048 L / j
$$

Each metal load $(\mathrm{C})$ is evaluated as follow:

$$
C=\text { Average concentration of metal } * Q
$$

These loads and the average concentrations of the various heavy metals are presented in table 3 . The average loads are compared to the beninese norms of effluents discharge in natural environments. Sum up, the heavy metals loads in the effluents are in the following order: $\mathrm{C}(\mathrm{Fe})>\mathrm{C}(\mathrm{Pb})>$ $\mathrm{C}(\mathrm{Cd})>\mathrm{C}(\mathrm{Hg})$.

Table 3. Average daily concentration and average load of metals contained in the effluents discharged into the lagoon.

\begin{tabular}{llll}
\hline Parameters & Means \& Standard deviation $(\mathbf{m g} / \mathbf{l})$ & Average $\mathbf{l o a d}(\mathbf{m g} / \mathbf{j})$ & Beneneses standard $(\mathbf{m g} / \mathbf{j})$ \\
\hline Lead & $0.1727 \pm 0.1018$ & $19698.94 \pm 11609.11$ & 5 \\
Cadmium & $0.0261 \pm 0.0072$ & $2976.65 \pm 821.83$ & 5 \\
Mercury & $0.0009 \pm 0.0002$ & $102.64 \pm 22.81$ & 0.1 \\
Total iron & $0.2500 \pm 0.1407$ & $28512 \pm 16047.98$ & - \\
\hline
\end{tabular}

The correlation matrix between heavy metals and abiotic variables (Table 4) shows that there is no correlation between the presence of heavy metals in the effluents and these parameters. There is still a significant correlation between electrical

\begin{tabular}{|c|c|c|c|c|c|c|c|c|c|}
\hline Variable & Temp & pH & Cond & TDS & DissOxy & $\mathbf{P b}$ & Cd & $\mathrm{Hg}$ & Total iron \\
\hline Temp & 1.00 & & & & & & & & \\
\hline $\mathrm{pH}$ & -0.92 & 1.00 & & & & & & & \\
\hline Cond & 0.59 & -0.79 & 1.00 & & & & & & \\
\hline TDS & 0.69 & -0.84 & 0.99 & 1.00 & & & & & \\
\hline DissOxy & -0.38 & 0.00 & 0.30 & 0.18 & 1.00 & & & & \\
\hline $\mathrm{Pb}$ & 0.04 & 0.01 & -0.56 & -0.53 & -0.04 & 1.00 & & & \\
\hline $\mathrm{Hg}$ & 0.30 & -0.09 & -0.54 & -0.46 & -0.50 & 0.88 & 0.66 & 1.00 & \\
\hline Total iron & -0.16 & 0.26 & 0.22 & 0.21 & -0.28 & -0.91 & -0.75 & -0.68 & 1.00 \\
\hline
\end{tabular}
conductivity and TDS $(\mathrm{r}=0.99 ; \mathrm{P}<0.01)$.

Table 4. Matrix of correlation of physicochemical parameters with heavy metals $(N=04$ samples).

Significant correlations marked at $\mathrm{p}<0.05$

\subsubsection{Hazard Assessment}

Hazards assessment for aquatic ecosystems of the studied hospital effluents consisted in comparing results obtained with the norms [21] presented in Table 1 for physico-chemical parameters and heavy metals contents. This comparison is showed in Table 5. We have considered the Beninese standard for average measured values $(\mathrm{Cp})$ and the threshold (Vs) ratios $(\mathrm{Cp} / \mathrm{Vs})$

\begin{tabular}{|c|c|c|c|c|}
\hline Parameters (mg/l) & Unity & Average Mesured values (Cp) & Threshold (Vs) & Ratio Cp/Vs \\
\hline Température & ${ }^{\circ} \mathrm{C}$ & 29.60 & - & - \\
\hline $\mathrm{pH}$ & & 7.95 & $6-9$ & $<1$ \\
\hline Dissolved oxygène & $\mathrm{Mg} / \mathrm{l}$ & 0.22 & $\geq 5$ & $<1^{*}$ \\
\hline Electric Conductivity & $\mu \mathrm{S} / \mathrm{cm}$ & 639.60 & 2000 & $<1$ \\
\hline TDS & $\mathrm{mg} / 1$ & 457.48 & - & - \\
\hline Lead & $\mathrm{mg} / 1$ & 0.1727 & 1 & $<1$ \\
\hline Mercury & $\mathrm{mg} / 1$ & 0.0010 & 0.03 & $<1$ \\
\hline Total iron & $\mathrm{mg} / 1$ & 0.2500 & - & - \\
\hline
\end{tabular}
calculation. The $\mathrm{Cp} / \mathrm{Vs}$ ratios are lower than 1 for all physicochemical parameters and heavy metals.

Table 5. Comparison of Maximum Measured Concentrations with Threshold Values Established for Hazard Characterization.

* For dissolved oxygen the ratio $\mathrm{Cp} / \mathrm{Vs}$ should be higher.

When we consider the load of heavy metals $(\mathrm{Pb}, \mathrm{Cd}$, and $\mathrm{Hg}$ ) spilled daily in the lagoon, we notice that the effluents present a great risk for the aquatic organisms (Table 6). 
Table 6. Comparison of average load of metals with Threshold Values Established for Hazard Characterization.

\begin{tabular}{llll}
\hline Parameters & $\begin{array}{l}\text { Average load } \\
(\mathbf{m g} / \mathbf{j})\end{array}$ & $\begin{array}{l}\text { Beneneses } \\
\text { standard }(\mathbf{m g} / \mathbf{j})\end{array}$ & Ratio Cp/Vs \\
\hline Lead & $19698.94 \pm 11609.11$ & 5 & 3939.788 \\
Cadmium & $2976.65 \pm 821.83$ & 5 & 595.33 \\
Mercury & $102.64 \pm 22.81$ & 0.1 & 1026.4 \\
\hline
\end{tabular}

\section{Discussion}

The comparison of the averages of all the parameters with several standards shows that the measured values are consistent, with all considered standards except, the case of dissolved oxygen. The table 2 shows that for lead, cadmium and mercury $\mathrm{P}$ is well below $0.05(\mathrm{P}<0.05)$.

Temperature and $\mathrm{pH}$ values being for the most part greater than $15{ }^{\circ} \mathrm{C}$ for former and between 5.5 and 8.5 for the later, are favorable to the micro-organisms development [22-23].

The mineralization of these effluents is moderate. Indeed, most of the recorded electrical conductivity values are between 333 and $666 \mu \mathrm{S} / \mathrm{cm}$ (table 1) except from the first sampling where the recorded value is equivalent in average to $1273 \mu \mathrm{S} / \mathrm{cm}$ [24]. These values are lower than those obtained by Adanlokonon et al. (2018) on the hospital effluents that led them to conclude that CHU-MEL effluents discharged into the Cotonou lagoon are highly mineralized. These differences may depend on the origin of the effluents (the hospital has several medical services) and the timing of their sampling. Indeed, studies have shown that the effluents parameters vary according to the hospitals specificities, the place and even the time of sampling during a day [25-27].

The average value of dissolved oxygen is very low $(0.22$ $\mathrm{mg} / \mathrm{l}$ ) and even lower than both admitted standard in Benin (5 $\mathrm{mg} / \mathrm{L}$ ) and that one recommended by "L'Ordonance sur le Déversement des Eaux usées" (ODE) which is $6 \mathrm{mg} / \mathrm{L}$. It is also lower than the critical threshold $(4 \mathrm{mg} / \mathrm{L})$ below which, aerobic microorganisms life is threatened [28]. This low oxygenation of water is due to a large consumption of dissolved oxygen by the aerobic bacteria for the degradation of organic matter [29]. It gives the environment an anoxic character and therefore a reductor and an asphyxiating chacacter. Thus, this area could promote the reduction of nitrates and sulphates respectively into nitrites and sulphides. Such a modification may be responsible for the unpleasant odors of the effluents [24]. [11] made the same remarks on the same hospital effluents.

Lead, cadmium and mercury are toxics that can be accumulated in aquatic food products. They can cause a number of disturbances in humans: renal, bone, neurological and / or digestive damages, carcinogenic and/or mutagenic disorders [30-31].

Several studies $[4,6,21,32,33]$ such as ours, have revealed low levels of contamination of hospital effluents by heavy metals. In addition, the assessment of the hazard (Table 5) due to the discharge of these effluents in Cotonou lagoon has shown that these effluents do not pose a great danger. Indeed, the $\mathrm{Cp} / \mathrm{Vs}$ ratios are less than 1 for all physicochemical parameters and heavy metals [21]. However, although these concentrations are low, the continued introduction of heavy metals into the aquatic environment is causing adverse effects on aquatic organisms because of their bioaccumulation and biomagnification properties [34-35]. It is thus important to determine heavy metals load in effluents of CHU-MEL daily discharged in the Cotonou Lagoon. Table 3 shows indeed that, heavy metals $(\mathrm{Pb}, \mathrm{Cd}$ and $\mathrm{Hg})$ taken into account in this study, have an average charges (19698.94 mg/day; $2976.65 \mathrm{mg} /$ day; $102.64 \mathrm{mg} /$ day) that far exceed the Benin threshold values. The discharge of these effluents into the lagoon presents potential risks for the organisms. It is therefore necessary to evaluate the ecotoxicological risks, as recommend by Emmanuel et al. [38]. Nevertheless, these results reveal that the assessed risk is low for aquatic organisms in the receiving environment. The flow of water in Cotonou lagoon being 182 $\mathrm{m}^{3} / \mathrm{s}$ during floods and slightly less during the low-water period [36], allows effluents dilution large enough to limit ecotoxicological risk. It should be noticed that, due to the presence of some bio-accumulative and persistent pollutants (some drugs including anti-cancer, certain organochlorine compounds.....), effluents discharged into the lagoon could have very long-term negative impacts for the organisms $[3,37]$.

\section{Conclusion}

Heavy metals contents assessment of CHU-MEL effluents and their risks for Cotonou lagoon have been conducted in this study. Results revealed a low level of contamination of CHU-MEL effluents discharged into the Cotonou lagoon by heavy metals $(\mathrm{Pb}, \mathrm{Cd}$ and $\mathrm{Hg})$ which are considered toxic. This fact added to the dilution effect of the effluents in the waters of the lagoon show that effluents discharge in the lagoon present low risks to the aquatic organisms of the receiving environment. However the continual discharge of these effluents into the lagoon could lead to heavy metal and other persistent pollutants accumulation in the aquatic food chain in fact, that is likely to cause long-term adverse effects on aquatic organisms.

Despite the low concentrations measured, the heavy metal load $(\mathrm{Pb}, \mathrm{Cd}$ and $\mathrm{Hg})$ discharged daily in the lagoon far exceeds the values accepted in Benin (nearly 4000 times for lead, 600 times for cadmium and more than 1000 times for mercury). This observation poses a real environmental problem as regards the discharge of CHU-MEL effluents into the Cotonou Lagoon. It is therefore necessary to evaluate the ecotoxicological risks of CHU-MEL effluents that are daily discharged into Cotonou Lagoon.

\section{Conflict of Interest}

The authors declare that they have no conflict of interest

\section{Acknowledgements}

We express our sincere gratitude to the General Direction 
of the Environment and Climate (DGEC) and its Director, Professor Martin Pépin AÏNA for allowing us to do a training session at the Environmental Monitoring Laboratory (LSE) which had been relevant in mercury measurement performing.

\section{References}

[1] OMS (Organisation mondiale de la santé) (1968). Lutte contre la pollution des eaux dans les pays en voie de développement. Rapport technique n${ }^{\circ} 404$. OMS. Genève, 42.

[2] Manda B. K., G. Colinet, L. André, A. C. Manda, J. P. Marquet and J. C. Micha (2010). Evaluation de la contamination de la chaîne trophique par les éléments traces $(\mathrm{Cu}, \mathrm{Co}, \mathrm{Zn}, \mathrm{Pb}, \mathrm{Cd}, \mathrm{U}, \mathrm{V}$ et As) dans le bassin de la Lufira supérieure (Katanga/RD Congo). Tropicultura 28 (4), 246252.

[3] C. Boillot (2008). Évaluation des risques écotoxicologiques liés aux rejets d'effluents hospitaliers dans les milieux aquatiques: Contribution à l'amélioration de la phase «caractérisation des effets». Thèse de doctorat, Institut National des Sciences Appliquées de Lyon, Lyon, France, 292p.

[4] Boillot, C., C. Bazin, F. Tissot-Guerraz, J. Droguet, M. Perraud, J. C. Cetre, D. Trepo and Y. Perrodin (2008). Daily physicochemical, microbiological and ecotoxicological fluctuations of a hospital effluent according to technical and care activities. Science of the Total Environment 403, 113 129.

[5] Berrada S., F. Z. Squalli, H. T. Squalli, M. Hannin, A. El Oualti and A. El Ouali Lalami (2014). Recyclage des effluents du service d'hémodialyse de l'hôpital Al Ghassani de la ville de Fès: caractérisation avant et après traitement. J. Mater. Environ. Sci 5 (S1), 2265-2277.

[6] Toure A., A. Garat, C. Diop, M. Cabral, M. J. Epote, E. Leroy, M. Fall, A. Diouf, B. Dehon and D. Allorge (2016). Présence de métaux lourds et de résidus médicamenteux dans les effluents des établissements de santé de Dakar (Sénégal). Int. J. Biol. Chem. Sci 10 (3), 1422-1432. DOI: http://dx.doi.org/10.4314/ijbcs.v10i3.40.

[7] Atolaye B. O. and M. O. Aremu (2007). Bioaccumulation of some trace elements in the body parts of fish species associated with soil sediment and water from Eoemaganiâ confluence in nasarawa state, Nigeria. EJEAFChe 6 (5), 20012008.

[8] Canli M. and Ö. A. M. Kalay (1998). Level of heavy metals $(\mathrm{Cd}, \mathrm{Pb}, \mathrm{Cu}, \mathrm{Cr}$ and $\mathrm{Ni}$ ) in tissue of Cyprinus carpio, Barbus capito and Chondrostoma regium from the Seyhan River, Turkey. Turkish Journal of Zoology 22, 149-157.

[9] République du Bénin (2006). Décret N²006-087 du 08 mars 2006 portant politique nationale d'hygiène hospitalière en république du Bénin. Journal Officiel de la République du Bénin.

[10] Makoutodé M., O. Touré, A. Yarou and A. M. d'Almeida (2000). Traitement des déchets liquides au Centre National Hospitalier Universitaire de Cotonou au Bénin. Le Bénin Médical 16, 29-34.

[11] Adanlokonon, E. A. S., Kanhounnon W. G., Chabi B. C.,
Adjahouinou D. C., Koumolou L., Bonou B., Fiogbe E. D. and P. A. Edorh (2018). Physicochemical and microbiological characterization of effluents from the "Centre Hospitalier Universitaire de la Mère et de l'Enfant Lagune (CHU-MEL)" discharged in the Cotonou lagoon in Benin. Int. J. Biol. Chem. Sci 12 (4), 1955-1964. DOI: 10.4314/ijbcs.v12i4.34.

[12] Adjahouinou, D. C., B. Yehouenou, M. N. D. Liady and E. D. Fiogbe (2014). Caractérisation bactériologique des eaux résiduaires brutes de la ville de Cotonou (Bénin). Journal of Applied Biosciences 78, 6705-6713.

[13] Adam K. S. and M. Boko (1993). Le Bénin (collection $n^{\circ} 26$, 5eme edn). Edicef: France.

[14] US. EPA (United States Environmental Protection Agency). (2007). Mercury in solids and solutions by thermal decomposition, amalgamation, and atomic absorption spectrophotometry. METHOD 7473. Retrieved May 28, 2019, from http://www.epa.gov/SW-846/pdfs/7473.pdf.

[15] Snedecor G. W. and W. G. Cochram (1962). Factorial Experiments. In Statistical methods- Oxford and IBM Publishing Co. Calcutta, 339-380.

[16] Adingra A. A., A. N. Kouadio, M. C. Blé, A. M. Kouassi (2012). Bacteriological analysis of surface water collected from the Grand-Lahou lagoon, Côte d'ivoire. African Journal of Microbiology Research 6 (13), 3097-3105.

[17] MEHU (Ministère de l'Environnement de l'Habitat et de l’Urbanisme)/Bénin (2001). Décret N²001-109 de 4 avril 2001 fixant les normes de qualité des eaux résiduaires en République du Bénin.

[18] EEAA (Egyptian Environmental Affairs Agency) (1994). Law number 4 of 1994 promulgating the environmental law and its executive regulation, Egypt.

[19] MATE (Ministère de l'aménagement du territoire et de l'environnement) (1998). Arrêté du 2 février 1998 relatif aux prélèvements et à la consommation d'eau ainsi qu'aux émissions de toute nature des installations classées pour la protection de l'environnement soumises à autorisation, J. Officiel de la France 52, 32-47.

[20] MATEE (Ministère de l'Aménagement, du Territoire, de l'Eau et de l'Environnement) /Royaume du Maroc (2005). Décret $n^{\circ}$ 2-04-553 24 janvier 2005 relatif aux déversements, écoulements, rejets, dépôts directs ou indirects dans les eaux superficielles ou souterraines.

[21] Emmanuel E., Y. Perrodin, G. Keck, J. M. Blanchard and P. Vermande (2005a). Ecotoxicological risk assessment of hospital wastewater: a proposed framework for raw effluents discharging into urban sewer network. J. Hazard Mater 117, $1-11$.

[22] Rodier J., Bazin C., Broutin J. P., Chambon P., Champsaur H., Rodier L. (1996). L'Analyse de l'Eau. (8 édn). Paris: Dunod, 1384 p.

[23] Mara D. (1980). Sewage treatment in hot climates. Ed. John Willey \& sons. $168 \mathrm{p}$.

[24] Rodier J., B. Legube, N. Merlet, R. Brunet (2009). L'Analyse de l'Eau ( $9^{\mathrm{e}}$ édn). Paris: Dunod. 1579.

[25] Hartemann P., A. Hautemaniere and M. Joyeux (2005). La problématique des effluents hospitaliers. Hygiène 13 (5), 369374. 
[26] Leprat P., C. Maftah, and C. Dagot (2002). Genotoxic activity of hospital wastewater: Behaviour of antineoplastic drugs in WWTP. In: New life for waste. Mons - Belgique. Province de Hainault, InNISMa, RECYWALL, FPMs., 122-126.

[27] R. Mohee (2005). Medical wastes characterization in healthcare institutions in Mauritius. Waste Management 25 (6), 575-581.

[28] S. Cornaz (2004). Evaluation du statut trophique d'un canal de drainage sous l'impact des pollutions d'origines diffuses et ponctuelles, le cas du grand canal de plaine de Rhône. Institut de Géographie de l'Université de Lausanne, Lausanne, 180.

[29] Hamaidi M. S., F. Hamaidi, A. Zoubiri, F. Benouaklil and Y. Dhan (2009). Etude de ladynamique des populations phytoplanctoniques et résultats préliminaires sur les blooms toxiques a cyanobacteries dans le barrage de Ghrib (Ain Defla-Algérie). European Journal of Scientific Research 32 (3), 369-380.

[30] Oliveira H., Lopes T., Almeida T., Pereira M. L., Santos C. (2012). Cadmium-induced genetic instability in mice testis. Hum Exp Toxicol., $31 \quad$ (12), 1228-1236. http://dx.doi.org/10.1177/0960327112445937.

[31] Prozialeck W. C and J. R. Edwards (2012). Mechanisms of Cadmium-Induced Proximal Tubule Injury: New Insights with Implications for Biomonitoring and Therapeutic Interventions. J Pharmacol Exp Ther. 343 (1), 2-12. http://dx.doi.org/10.1124/jpet.110.166769.

[32] Amouei A., Asgharnia H., Fallah H., Faraji H., Barari R.,
Naghipour D. (2015). Characteristics of Effluent Wastewater in Hospitals of Babol University of Medical Sciences, Babol, Iran. Health Scope, 4 (2), 1-4.

[33] Orias F. and Y. Perrodin (2013). Characterisation of the ecotoxicity of hospital effluents: A review. Science of the Total Environment 454-455, 250-276.

[34] Lim S. R. and J. M. Schoenung (2010). Human health and ecological toxicity potentials due to heavy metal content in waste electronic devices with flat panel displays. Journal of Hazardous Materials 177, 251-259. DOI: 10.1016/j.jhazmat.2009.12.025.

[35] Baby J, Raj JS, ET Biby, Etsankarganesh P, Jeevitha MV, Ajisha SU, Rajan SS. (2010). Toxic effect of heavy metals on aquatic environment. Int. J. Biol. Chem. Sci., 4 (4), 939-952. http://ajol.info/index.php/ijbcs.

[36] D. Mama (2010). Méthodologie et résultats du diagnostic de l'eutrophisation du lac Nokoué (Benin). Thèse de doctorat, Université de Limoges. 157.

[37] Emmanuel E., K. Hanna, C. Bazin, G. Keck, B. Clement and Y. Perrodin (2005b). Fate of glutaraldehyde in hospital wastewater and combined effects of glutaraldehyde and surfactants on aquatic organisms. Environ Int 31: 399-406.

[38] Emmanuel E., Y. Perrodin, J. M. Blanchard, G. Keck and P. Vermande (2004). Approche méthodologique de l'évaluation des risques écotoxicologiques des effluents hospitaliers vis-àvis de la step locale et de l'écosystème aquatique récepteur. Revue francophone d'écologie industrielle 35 (3): 18-27. 